\title{
Improving the quality of services at the University of Oviedo"
}

\author{
Alberto A. SuÁrez* Pablo AlbañIl ${ }^{* *}$ Javier Alonso*** \\ RAMIRO MARTÍS ${ }^{* * * *}$ CARLOS CATALÁN***** \\ MIGUEL ANGEL PASCUAL ${ }^{* * * * *}$
}

\begin{abstract}
Purpose of the paper: With the purpose of fostering a continuous improvement policy in the 25 services provided by the University of Oviedo aimed at increasing the quality, effectiveness and efficiency of these services, the Technical Quality Unit has drawn up a specific Quality Plan for Services.

The main goals are:

- To foster public information on the services provided and on the quality commitments assumed in their provision via the drawing up of Service Charters to users.

- To improve the quality and efficiency of the services provided to users through the implementation of an Internal Quality Assurance System.

- The obtaining of external accreditations.

Methodology: We have followed the recommendations of the Spanish Royal Decree 951/2005 of 29 July, establishing the general framework for improving quality in General State Administration and UNE standard 93. 200:2008 (Requirements of the service charters) to design service charters. In relation to the design of Quality Management Systems (QMS), we used the ISO 9001:2008.
\end{abstract}

- Best paper for the $15^{\text {th }}$ Toulon-Verona Conference "Excellence in services", Tel-Aviv (Israel), 3-5 September 2012.

* Doctor in Industrial Engineering - Technical Unit for Quality - University of Oviedo e-mail: suarez@uniovi.es

** Degree in Biology - Technical Unit for Quality - University of Oviedo e-mail: albanilpablo.uo@uniovi.es

*** Degree in Chemistry - Technical Unit for Quality - University of Oviedo e-mail: alonsojavier@uniovi.es

**** Degree in Education - Technical Unit for Quality - University of Oviedo e-mail:martis@uniovi.es

***** Computer Engineering - Technical Unit for Quality - University of Oviedo e-mail: catalancarlos@uniovi.es

****** Mining Engineer - Technical Unit for Quality - University of Oviedo e-mail: pascualmiguel.uo@uniovi.es 
Findings: The monitoring of these quality commitments is carried out by means of 273 indicators. A software application has been designed to facilitate the uploading of data by users, the exploitation of results and the subsequent decision-making process. A pilot-test has been jointly carried out with the Research Service in the design of its Internal Quality Assurance System. Support is currently being provided to different services in the day-to-day job of adopting the aforementioned continuous improvement policy.

Research limits: The 25 services provided by the University of Oviedo.

Practical implications: The QMS must to be transversal to the entire University, including all the Áreas. This premise is essential to implement a culture of quality in the University.

Originality of the study: The developed application is equipped with "Cloud" technology. It gives advantages in terms of mobility, as it can access the platform from any device with internet connection.

Key words: university services; service charter; quality management systems; EFQM; Quality Plan.

\section{Premises and background of the study}

University autonomy is a key instrument for achieving the objectives of quality and progress in Higher Education. The result of this autonomy is the increasing requirement of accountability to demonstrate that the decisions and actions taken by the university are aimed at improving quality.

In the 1980s people started to talk about "quality of service", which is a very broad concept that was initially characterized by a clear focus on user satisfaction. This involves the carrying out of activities that reveal and respond to the needs and expectations of users and of the university community as a whole. This model follows William E. Deming's cycle of continuous improvement: plan (P), do (D), check (C) and act (A).

In the second half of the 1990s, the University Institutional Assessment became the central action driving improvement in university management processes at all levels (Teaching, Research and Services) throughout Europe with a common goal: to ensure "effectiveness and efficiency in University Institutions" (Mora, 1998).

With the Bologna Declaration of 1999, Academia began to prepare for the process of adaptation to the European Higher Education Area (EHEA). The main reason underlying its implementation is the search for mechanisms of compatibility and comparability among all European university systems so as to facilitate greater mobility to all students and graduates within the European Union in both the academic and professional sphere. That is, new space is being created through convergent reforms in different national settings (Haug, 2008) based on compatible quality accreditation systems so as to achieve mutual recognition between the different European educational institutions and determine compliance with established levels of quality (Egido and Haug, 2006).

Paragraph 1. 5 of the document on Standards and Guidelines for Quality Assurance in the European Higher Education Area: Learning resources and student 
support, describes the need for institutions to monitor, review and improve the effectiveness of student support services on a routine basis.

Spain's Statutory Law 6/2001 of 21 December, on Universities (Title V. Regarding Assessment and Accreditation) makes specific reference to Services in Article 31 , on quality assurance, which sets the goal of improving teaching and research and university management. It does so by establishing common criteria for quality assurance that facilitate the assessment, certification and accreditation of activities, programmes, services and management of higher education centres and institutions, among others.

The University Service Assessment may be considered "as an element of support to quality assurance" (Blaya, 2008) of studies, pursuing the goal of continuous improvement and overall satisfaction of stakeholders: teaching and research staff, administrative and services staff, students, graduates, employers, professional associations, other universities or other academic and/or research centres, and society in general.

The evolution of Quality Assurance in Spanish universities can be summarized in the following steps, seen from the standpoint of University Services:

- 1980s: Disconnected activities, student surveys, etc;

- 1992-1994: Experimental Quality Assessment Programme of the University System (Spanish acronym, PEXEC). (Tangential inclusion of services);

- 1994-1995: European Pilot Project Programme for Quality Assessment in Higher Education;

- 1995: Start-up of the National Plan for Quality Assessment in Universities (Spanish acronym, PNECU);

- 1996-2000: PNECU Calls for Projects (Including Services).

The assessment guidebook of the National Plan for Quality Assessment in Universities highlights that institutional assessment covers the entire institution, including teaching, research and services. However, due to the magnitude and volume of the institution, it may be undertaken in successive stages without losing sight of the fact that the institution taken as a whole and the involvement of all the actors concerned constitute its distinguishing features.

The first step in addressing a paradigm shift in the management of university services is to analyse the actual state in which the service finds itself. This may be undertaken via a self-evaluation process that allows strengths and opportunities for improvement to be identified. This in-house assessment process facilitates subsequent external recognition, which can enhance its objectivity, transparency and comparability with similar services, entering a dynamic that focuses on improving performance in the broadest sense of the term.

Support guides that adopt an EFQM-based approach (European Foundation for Quality Management) were drawn up for the assessment of services.

The PNECU's 1996-2000 general report specifies that processes are considered an important element of management. A weakness that is mentioned is the lack of process manuals $(24 \%)$. All services aim to improve processes and the systems for assessing them. Another suggestion for improvement identified in this report related 
to weaknesses is the drawing up of documentation on the service (24\%). The University of Oviedo Services did not participate in the PNECU's calls for projects.

2001-2006 (repealed in 2002): II University Quality Plan (Spanish acronym, PCU) (Including Services).

One of the objectives set out in the II University Quality Plan is to continue to promote institutional assessment and to foster the implementation in universities of comprehensive quality systems for continuous improvement

The memorandum, reproduced below, from the Spanish Ministry for Universities on the development of the II University Quality Plan highlights once again the assessment of services as a point to take into account as regards the quality of a university: the universities that respond to this call are to submit a multi-annual quality project, including the mandatory assessment of all the degrees implemented throughout the duration of the Plan and the review of the results thereof. The assessment and review of results, , of departments and general services in the same period may be included in the project on a voluntary basis.

The services assessed at the University of Oviedo in the two PCU II University Quality Plan calls were:

- $\quad$ scientific/Technical Services (2001);

- library Services (2001);

- halls of Residence (2002);

- university Extension (2002);

- research (2002).

2003/2004 - 2006/2007: the Institutional Assessment Programme (Spanish acronym, PEI) of the Spanish National Assessment and Accreditation Agency (ANECA) (Does not include services as such).

2003/2004: ANECA Accreditation Pilot Programme.

In parallel, ANECA published specific programmes and guidelines for assessing the Quality of University Services; for example, those applicable to Libraries and International Relations Offices:

2003/2004 - 2006/2007: University Library Services Quality Certificate,

2006/2007: Assessment of International Relations Offices,

2006: Assessment of University Services in accordance with the EFQM model, 2003/2004 - 2008/2009: Quality Distinction in PhD Programmes,

2007: AUDIT and VERIFICA Programmes,

2009: Campus of International Excellence.

The International Campus of Excellence Programme is part of the University 2015 Strategy to modernize Spanish universities. Order PRE/1996/2009 of 20 July establishing the rules for the awarding of public grants in order to introducethe International Campus of Excellence Programme in the Spanish university system refers to University Services as follows:

The development of new services or facilities that incorporate non-existing innovative technologies.

- scientific-technological services to support R\&D and Innovation;

- support and hosting services for international students; 
- support services for international post-graduate studies. Spanish Heritage Institutes. University Language Schools and self-education infrastructures;

- services for attending to students.

2010: Distincion to Excellence in PhD Programmes at Spanish Universities Distinction (call EDU/3429/2010).

Spanish University Services are currently implementing tools for improvement that allow them to respond to the requirements of the EHEA and provide information to improve their activities, as can be seen in the table below.

Tab. 1: Shares services summary of Spanish Universities

\begin{tabular}{|lcc|}
\hline \multicolumn{1}{|c}{ Actions developed } & $\begin{array}{c}\text { Number of } \\
\text { Universities }\end{array}$ & $\%$ \\
\hline Service Charters & 40 & 88,89 \\
\hline Actions related to EFQM model & 15 & 33,33 \\
\hline Process and procedures & 13 & 28,89 \\
\hline Evaluation and self-evaluation of the Service & 12 & 26,67 \\
\hline Systems of Quality Management & 7 & 15,56 \\
\hline $\begin{array}{l}\text { Drawing up of an assessment, quality, improvement, } \\
\text { strategy Plan/Programme for Services }\end{array}$ & 5 & 11,11 \\
\hline Actions related to ISO Standard 9001:2008 & 4 & 8,89 \\
\hline Manual/Guidebook for process design/assessment & 3 & 6,67 \\
\hline
\end{tabular}

Source:Data from the review of different university websites in May 2012. Total number of Universities studied: 45.

From the results shown in the table above, it can be understood that the majority of Spanish Universities (88. 89\%) took the drafting of Service Charters as their starting point to inform their stakeholders about the activities they undertake.

Similarly, there have been several actions aimed at the systematization, organisation and documentation of the activities carried out by the Services, either by the application of self-assessment models (e.g. EFQM) and the design and implementation of Quality Management Systems activities by developing processes and procedures that provide support the different activities.

The main objective of this paper is to present the initiatives being developed in Service Quality Management at the University of Oviedo in relation to the actions of other Spanish Universities and the applicable requirements, such as adaptation of studies to the European Higher Education Area, the International Campus of Excellence Programme and the University 2015 Strategy. The paper also analyses, using a simple 1 to 5 points Likert scale questionnaire for the Heads of Service and users, whether the implemented initiatives (process manuals and service charters) have met the objectives established at the beginning of the project regarding the improvement of information about the service, the systematization of activities, the efficiency of resource management and monitoring of the Quality System by means of indicators. 


\section{Methodology followed in the study}

The need to establish quality assurance criteria that facilitate assessment, certification and accreditation considers quality assurance as an essential aim of university policy across the board. On the basis of these requirements, the University of Oviedo - via its Technical Unit for Quality and in collaboration with its Services launched the activities of drawing up and implementing process manuals (Quality Management System) and service charters to meet the criteria and guidelines for quality assurance established in the European Higher Education Area, aimed at achieving the following objectives:

1. to raise awareness regarding service quality, with a training plan for Administrative and Services Staff;

2. to analyse the current status of the service in terms of quality, through meetings with the assigned technical staff;

3 . to design a process manual and service charter. To establish indicators and quality commitments with users;

4. the Way to Quality of Service is Continuous Improvement.

Fig. 1: Improvement of the service

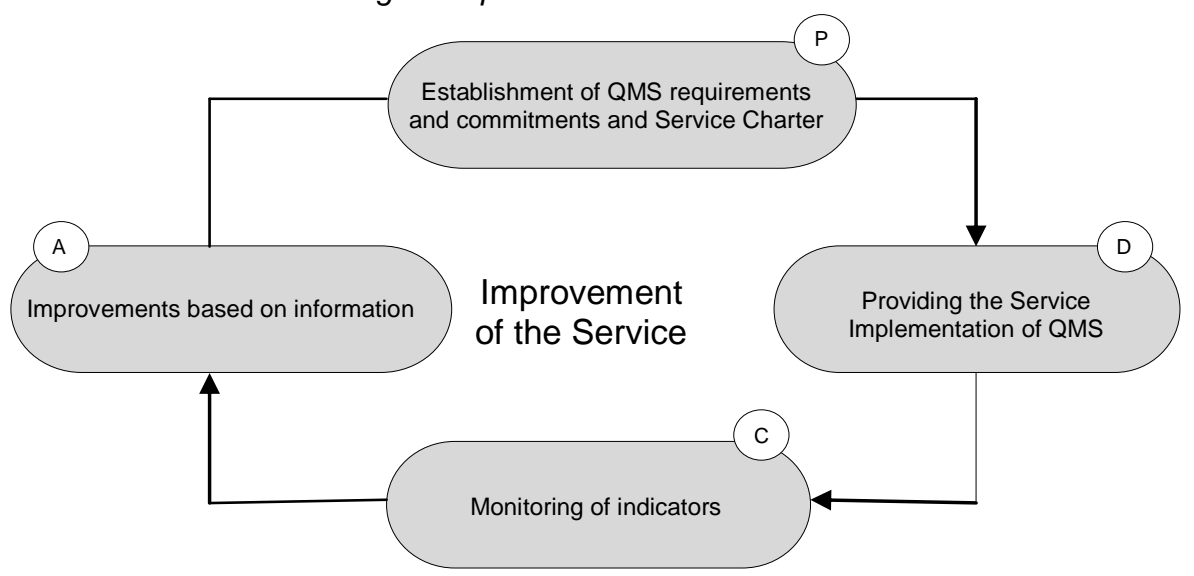

Source: Prepared by the University of Oviedo

The Quality Plan for Services was drawn up by the Technical Unit for Quality and approved by the Management Team at the University of Oviedo. It comprises the following three lines of action:

1. Drawing up of Service Charters (a document which constitutes the instrument through which organisations inform users about the services commissioned, the rights they have and quality commitments in terms of service provision) for the 25 services provided by the university. This line of action is intended to:

a. make information available to users about the services provided;

b. inform users of the channels for communicating incidents and suggestions; 
c. act as a starting point for aiming university services towards a policy of continuous improvement;

d. publicize the quality commitments that have been adopted;

e. check the degree of compliance with quality commitments by monitoring the associated indicators.

The adopted recommendations are those of Spanish Royal Decree 951/2005 of 29 July, establishing the general framework for improving quality in General State Administration and UNE standard 93. 200:2008. Service charters. Requirements.

The following information was chosen to be included in the service charters:

Fig. 2: Scheme of the information to include in the service charter
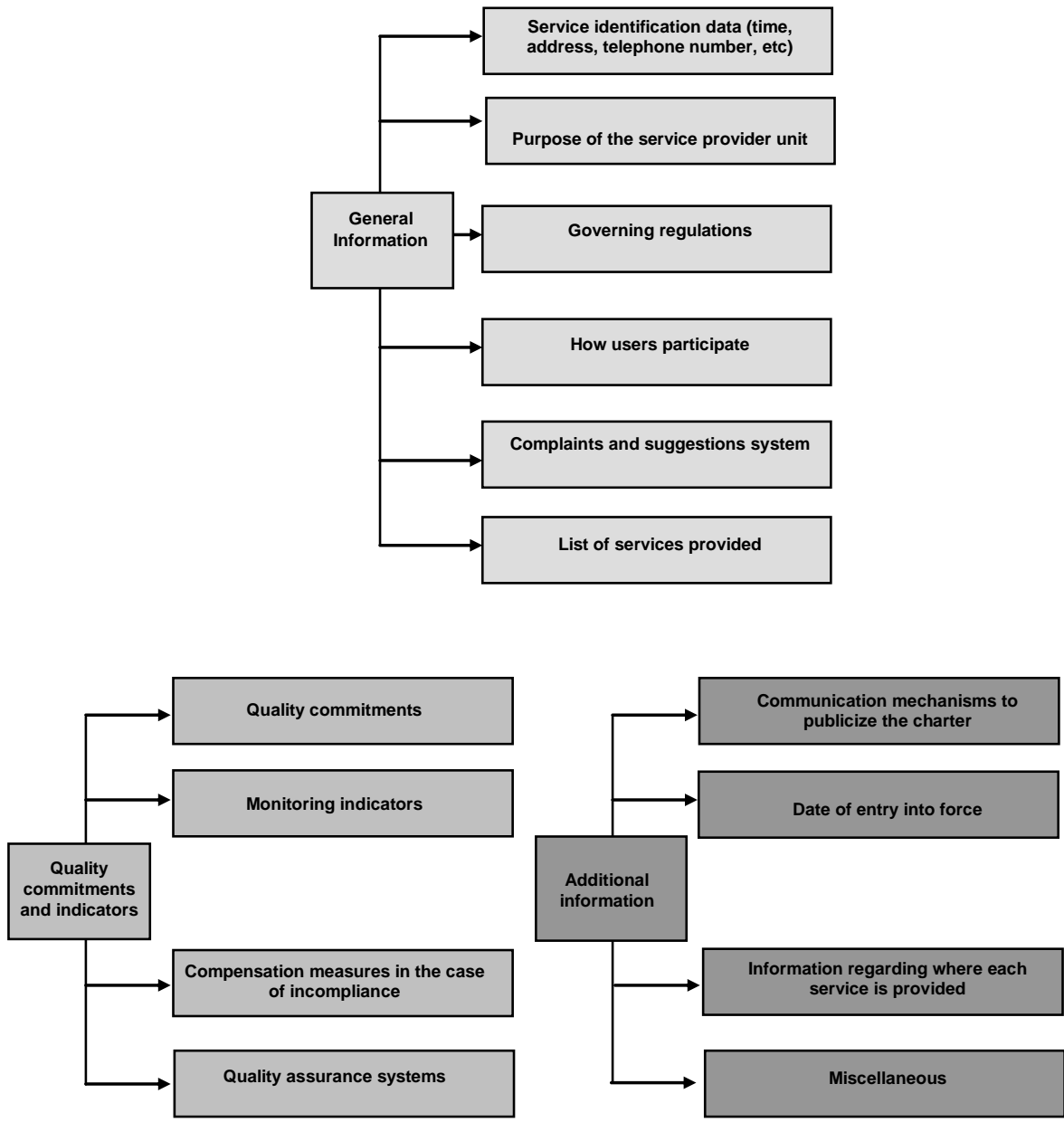

Source: UNE standard 93. 200:2008. Service charters. Requirements 
The main steps in the drafting of the charter were:

Fig. 3: Major milestones in the drafting and implementation of service charters

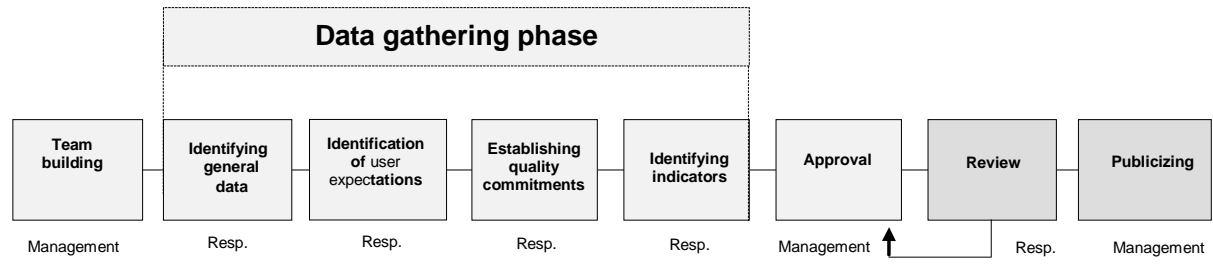

Source: the University of Oviedo

2. Design and implementation of a Quality Management System - Work Procedure Manual for each of the 25 services, following the process approach of the

Technical Unit for Quality (UTCal) of the University of Oviedo ${ }^{1}$. The objectives of this line of action are to:

a. systematize and unify the activities undertaken in the different university departments;

b. increase the efficiency of resources (time, information, financial, material, etc.);

c. facilitate the incorporation of new staff to the service;

d. monitor the activities performed by services via indicators that allow objective decisions to be taken regarding processes;

The systematizing of tasks was carried out through monthly meetings with each service.

Fig. 4: Major milestones in the design and implementation of the Quality Management System

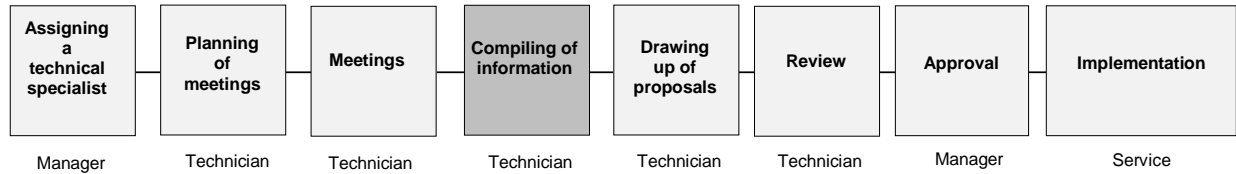

Source: Prepared by the University of Oviedo

ISO standard 9001:2008, adapted to the requirements of university services, was followed in the design of the service.

1 The methodology employed is registered as University of Oviedo publication "Metodología Innovadora para la Gestión por Procesos: GESTIONNA" [Innovative Methodology for Process Management: GESTIONNA]; legal deposit AS-2689-2011. 
3. Obtaining of external recognition for the services most involved. Not yet implemented, this line of action would consist in ISO 9001:2008 certification and/or EFQM recognition.

Via an anonymous assessment questionnaire, UTCal evaluated the satisfaction of the different services with the activities carried out by UTCal and with each of the lines of action in the Quality Plan. See the appended satisfaction survey:

\section{Results}

The project kicked off with its communication to all the Heads of Service by the Management Team during January and February 2011. The Head of the Technical Unit for Quality, along with the technical specialist assigned to the service, presented the project to each university service and organised the respective awareness-raising seminars.

\section{a. Service charters:}

The charters for the 25 university services were drawn up during 2011:

Tab. 2: University services

\begin{tabular}{|ll|}
\hline Recruitment and Heritage & Student and Employment Management \\
\hline Personnel Management & Research \\
University Libraries & University Extension \\
Legal requirements & Internationalisation and Cooperation for Development \\
Gijón Campus Administration & Infrastructure \\
Administrative Organisation and General Affairs & Budgetary and Financial Accounting \\
Mieres Campus Administration & Economic Planning \\
Computing and Communications (GAE) & Faculty, Departments and Centres \\
Computing and Communications & Process Control \\
Cost Accounting & Academic Affairs and New Degrees \\
Milán Campus Administration & University Services \\
Llamaquique Campus Administration & Cristo A Campus \\
Campus of Excellence & \\
\hline
\end{tabular}

Source: http://www.uniovi.es/descubreuo/centros/servicios

Eighty-four scheduled meetings, 93 visits and 152 calls were made in the drawing up of service charters, in addition to the 2,340 work hours logged by the Technical Unit for Quality.

Approval of service charters: Once approved, the service charters were published in the Official Gazette of the Principality of Asturias (BOPA), no. 4 of 7 January 2012.

https://sede. asturias. es/bopa/2012/01/07/2011-24446. pdf 
Fig. 5: Example of the charter for the Research Service

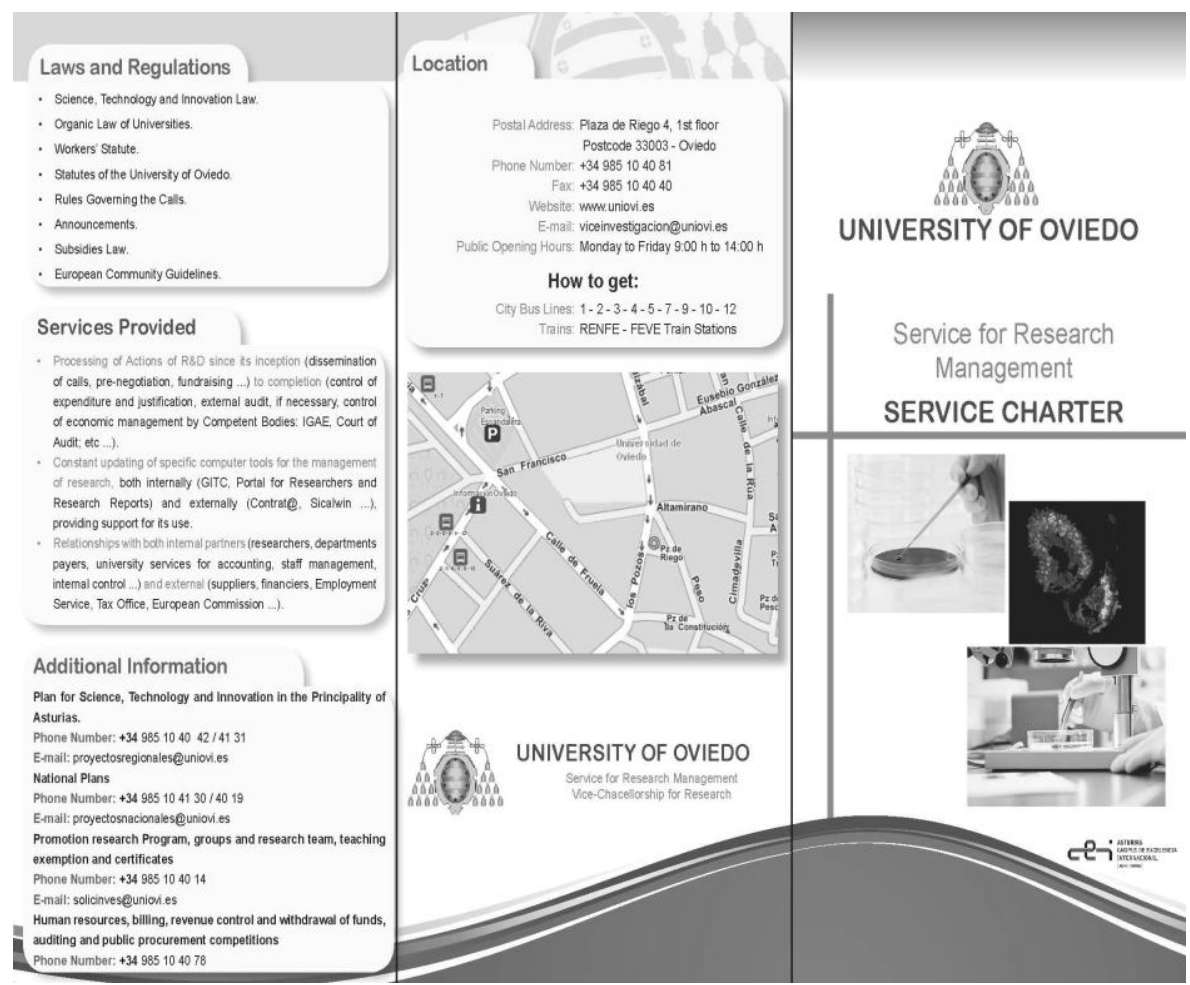

Source: http://calidad.uniovi.es/servicios/cartasservicio

Publicizing of service charters: The 32 drafted and approved service charters were publicized via the Technical Unit for Quality website.

http://www.uniovi.es/calidad/procesosutcal/cartaservicios Since it was published, the service charters have received 3,460 visits by June 2012. Implementation of service charters: Once the service charters had been published in the BOPA, their implementation commenced with the monitoring of the fulfilment of quality commitments.

A software application was designed to facilitate the uploading of data and the tracking of the indicators that monitor quality commitments. This application allows real-time monitoring of the implementation in each of the services and the analysis of the data coming from their indicators. Quarterly meetings are held to monitor their implementation and analyse the scores of the indicators, the degree of fulfilment of quality commitments, the evolution of the service and any changes produced. These meetings are becoming part of the routine activities of the service as quarterly service monitoring meetings. 


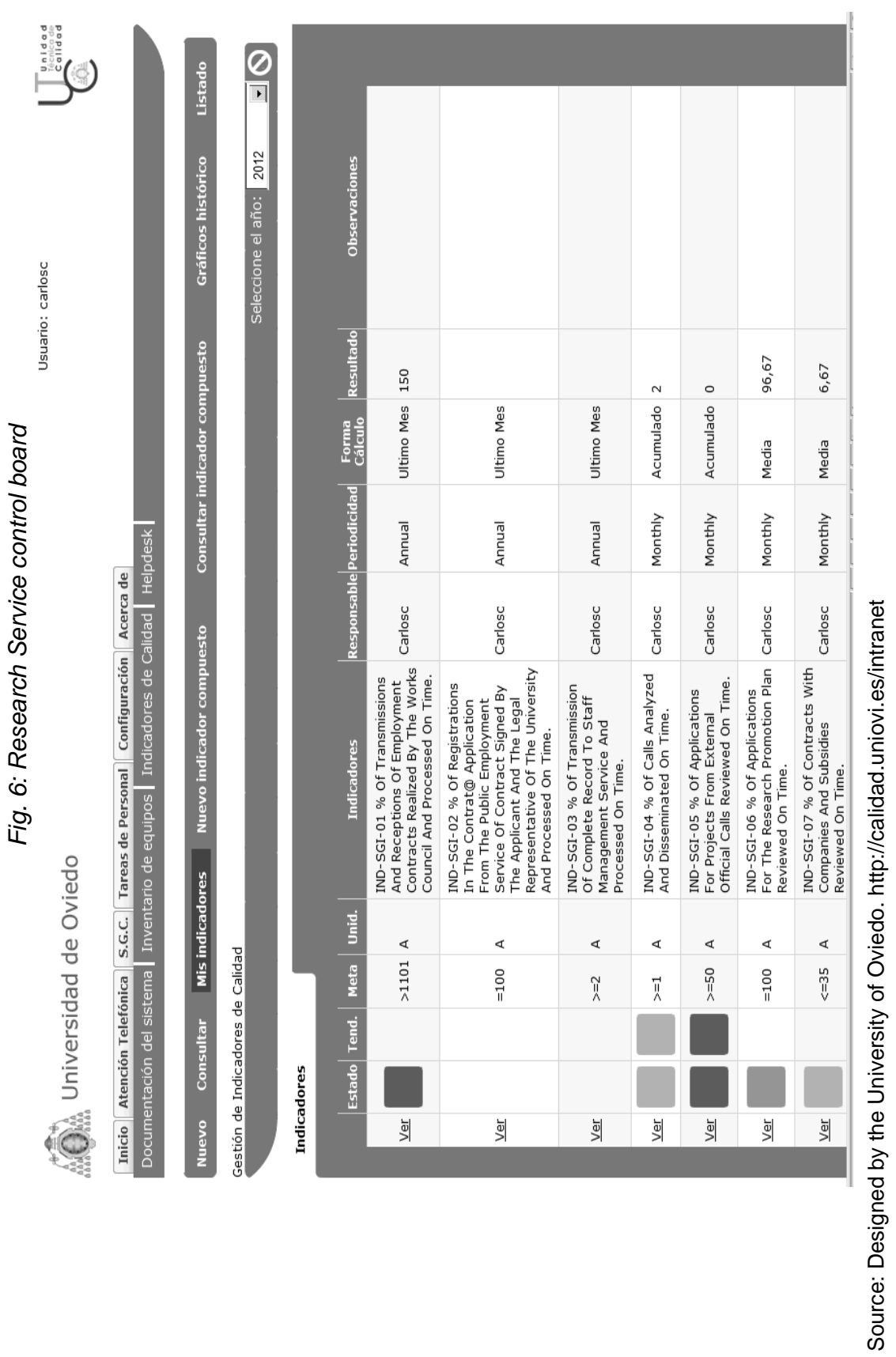




\section{b. Design and implementation of Quality Management Systems}

The Quality Management Systems are based on Process Management, which will mean a change in organisational culture in each service, aimed at "understanding the difference between the 'document what you draft approach and the 'process' approach to system development" (Hoyle and Thompson, 2000). Previous studies show that process management increases adaptation in stable environments, such as university services, and hence can be considered a good initiative (Ford et al., 2012). As it entails a profound paradigm shift, it is advisable to raise the awareness of and train everyone in the service facing this change. At the University of Oviedo, the Technical Unit for Quality provides training sessions for the different services aimed at transmitting the concepts, methodology, tools and steps to address the drawing up and implementation of process manuals upon request. They have a highly participatory component that reproduces the work methodology that should then be addressed in each of the services in the drafting and implementation phases. As the first line of action drew to a close in the different services, the design and implementation of the Quality Management System commenced following ISO standard 9001:2008 requisites with the help of the process approach of the Technical Unit for Quality. Work began on the core processes. In 2011, this line of action was started up in 18 of the 25 services, drafting 23 processes and 25 documented procedures. As of June 2012, 72 processes and 51 documented procedures have been drafted, 94 scheduled meetings and 20 visits to department have been held and 240 calls have been made.

Five technical specialists belonging to the University of Oviedo's Technical Unit for Quality have worked on the development of this line of action. As of June 2012, these technical specialists have logged a total of 5,694 work hours.

All the documents that make up the Quality Management System are published on the university's intranet and are accessible in read-only mode to the entire university staff. This measure is intended to:

- facilitate the implementation of the Quality Management System,

- assist new staff in their integration in the workplace,

- publicize the services provided, how they are carried out and by whom,

- make all institutional templates accessible in their latest version.

This repository was published on 16 May and receives an average of 67 visits per week. Approximately $30 \%$ of viewings areover 5 minutes.

As an example of the improvement resulting from the implementation of Quality Management Systems in university services, a pilot project was launched to gather suggestions and/or comments about the teaching support services offered by the Teacher Training Faculty. During the implementation period, there were 52 incidents, of which $32 \%$ were responded to and resolved immediately, $28 \%$ received an immediate response and $16 \%$ received no response. $24 \%$ required no response or/or solution. The overall score of the people who took part in the survey regarding the services offered at the centre was 6.08 (scale 0-10). 
Fig. 7: Documentary repository of the Quality Management Systems of the University of Oviedo Services

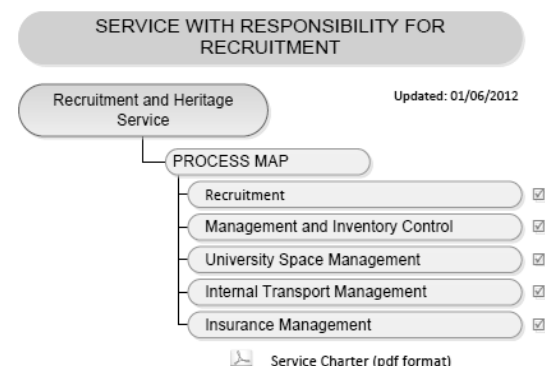

2. Service Charter (pdf format)

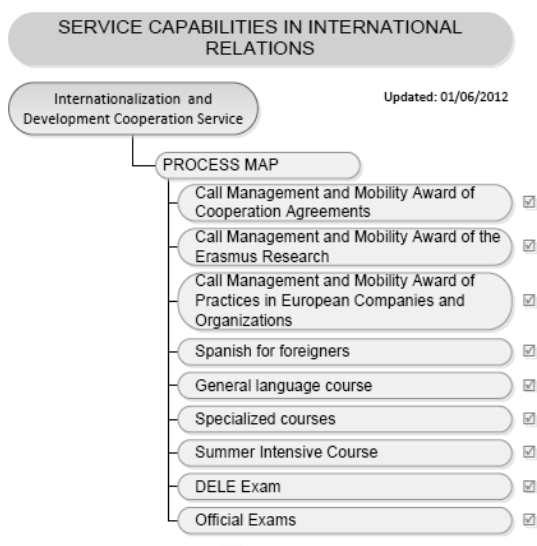

$\triangle$ Service Charter (pdf format)
SERVICE WITH RESPONSIBILITY FOR RESEARCH

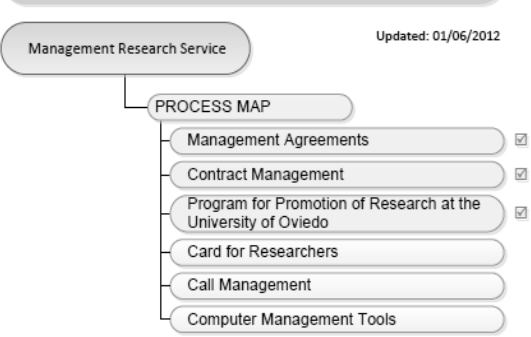

2. Service Charter (pdf format)

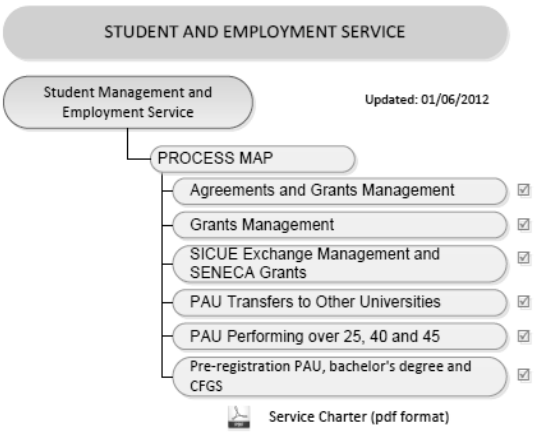

Source: the University of Oviedo. http://procesos.uniovi.es/mapaprocesos/ 

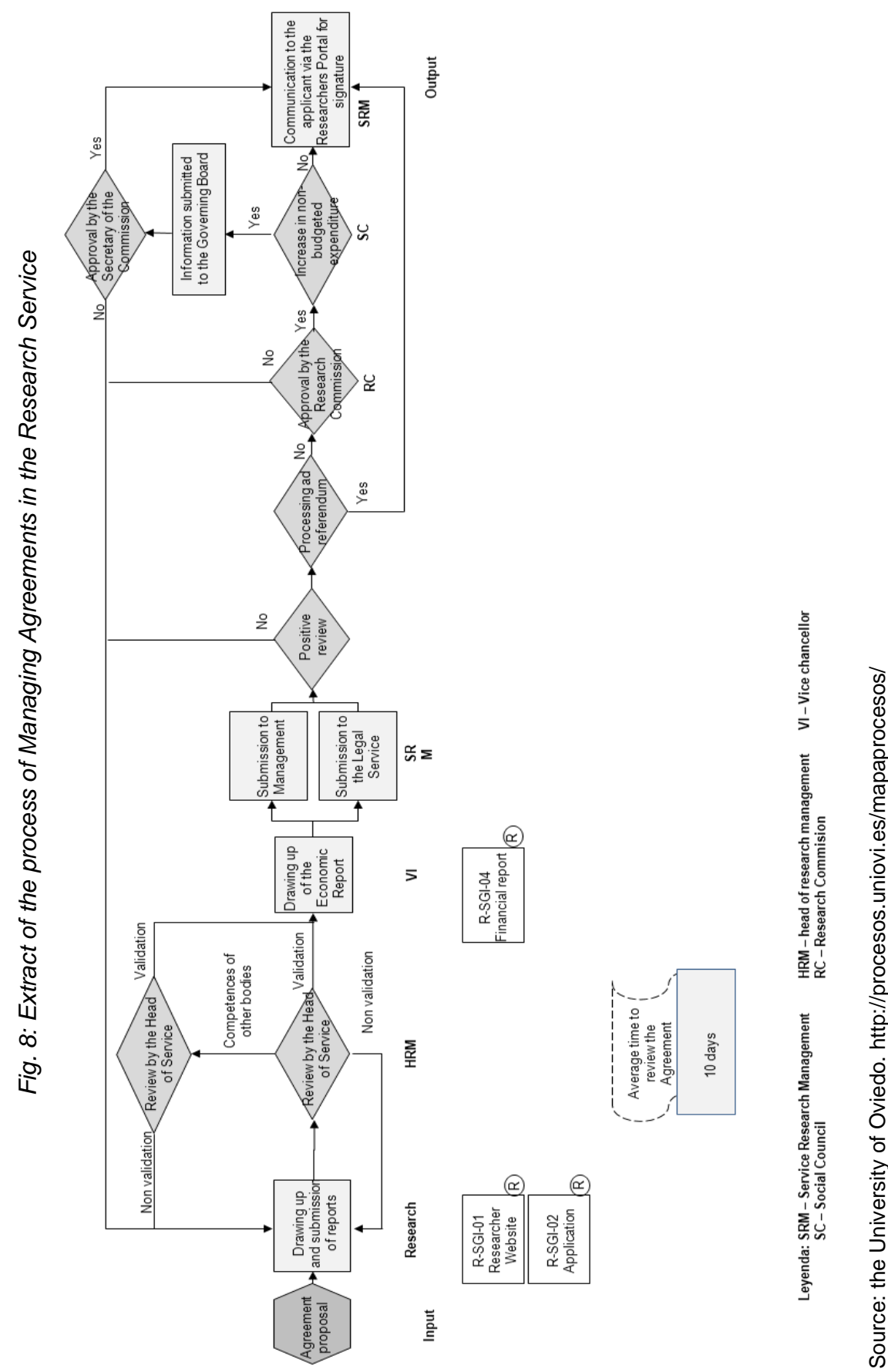


\section{Conclusions}

The key success factor of the service quality plan is the active involvement of staff. In meetings with the different services, most of the staff has been motivated and become involved. The results of the satisfaction survey of service personnel are considered very satisfactory, as the lowest ranked item has a score of 3.4 on a scale of 1 to 5 . The response rate was $50 \%$.

Fig. 9: Results of the satisfaction survey

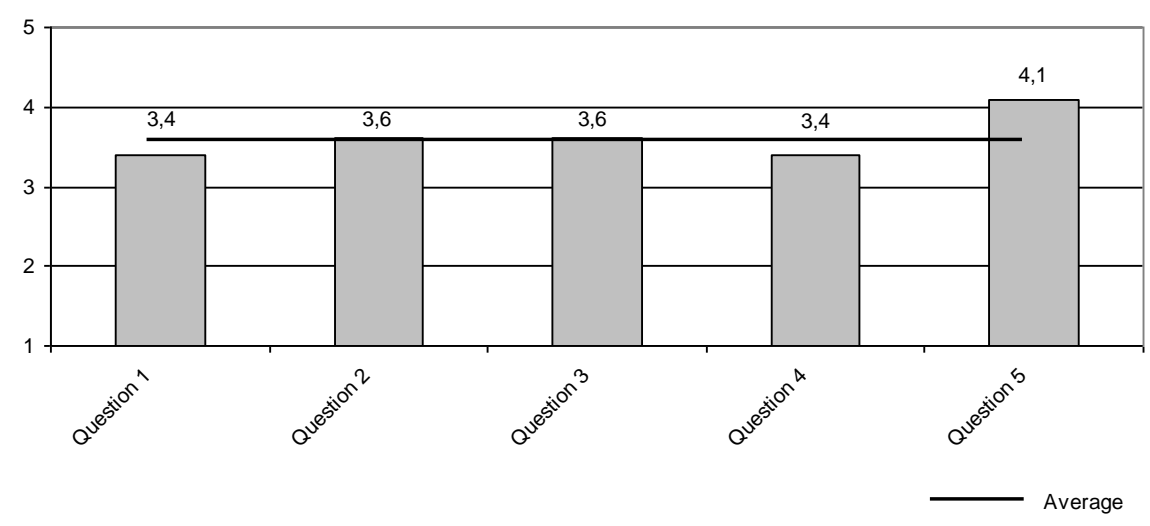

Source: Prepared by the University of Oviedo

See annex 1 The quality plan should be multi-annual and highly structured. This entails rethinking the purpose and design of management systems so as to build enduring services that create value not only for current stakeholders, but also for future generations of stakeholders (Latham, 2012). Planning should be tailored to each of the services so as to evolve linearly.

The conclusions drawn from the actions taken are:

- Service charters have been the starting point for continuous improvement in services. They have allowed all stakeholders to be informed of the existence of the service, of the services provided and of how to get in contact and communicate incidents and/or suggestions. The drawing up of the service charters has been very well received in services due to:

- the identification of the services provided and their publicizing;

- the informing of users of contact details, thus reducing the amount of calls to wrong numbers;

- the encouragement of improvements in the service by defining quality commitments and their monitoring through indicators.

- The second line of action of designing and implementing a Quality Management System: 
- facilitates document management, thus reducing search times and generating documents and templates of records;

- improves the incorporation of new staff, thus reducing the time needed for their integration and increasing the safety of new employees;

- monitors the development of the service by means of indicators of both service charters and processes;

- $\quad$ systematizes and standardizes the activities carried out in different services.

- integrates the different services.

A crucial factor in the implementation of the plan has been the incorporation of

IT tools that:

- facilitate the uploading of data and the monitoring of indicators;

- document management.

\section{References}

ABBATE T., ALIBRANDI A., SOUCA M., University and Sports: how to improve the CUS services?, 14th Toulon - Verona Conference "Organizational Excellence in Services", 1-3 September 2011, Conference Proceedings.

ÁLVAREZ SUÁREZ A. (2009), University Service Assessment in Accordance with the EFQM Excellence Model at the University of Oviedo, 12th Toulon-Verona.

ARIAS RODRÍGUEZ A. (2007), "Evaluación de la calidad en los servicios universitarios", disponible en: http://www.fiscalizacion.es/?p=686 (consultado el 26 Abril 2009).

BLAYA SALVADOR I. (2008), "Evaluación de los servicios universitarios", La garantía de la calidad en los nuevos planes de estudio, IX Foro de Almagro, Almagro, 25 y $26 \mathrm{de}$ Octubre de 2007, Universidad de Castilla La-Mancha, Ciudad Real, pp. 325-366.

CONSEJO DE COORDINACIÓN UNIVERSITARIA, Informe global 1996-2000, Plan Nacional de Evaluación de la Calidad de las Universidades.

EGIDO I., HAUG G. (2006), "La acreditación como mecanismo de garantía de la calidad: tendencias en el Espacio Europeo de Educación Superior", Revista Española de Educación Comparada, n. 12, pp. 81-112. http://www.sc.ehu.es/sfwseec/reec/reec12/reec1203.pdf

MORA J.G. (1998), "La Evaluación Institucional de la Universidad", Revista de Educación, 315 , pp. 29-44.

HAUG G. (2008), "Legislación europea y legislaciones nacionales", Revista de Educación (número extraordinario 2008), pp. 285-305. http://www.mecd.gob.es/dctm/revista-deeducacion/articulosre2008/re200812.pdf?documentId=0901e72b8120402c

HOYLE D.,THOMPSON J. (2000), Converting a Quality Management System using the Process Approach, $2^{\text {nd }}$ ed.,Transition Support.

LATHAM J.R. (2012),"Management System design for sustainable Excellence: framework, practices and considerations", Quality Management Journal (American Society for Quality), vol. 19, n. 2, pp. 7-21.

MATTHEW W. FORD, SUZANNE S. MASTERSON,JAMES R. EVANS (2012),“The road to maturity: Process management and integration of strategic human resources processes", Quality Management Journal (American Society for Quality), vol. 19, n. 2, pp. 30-46.

PEREIRA LOURO A., LOURENÇO L., SARAIVA P., Methodologies for integrated quality assessment in higher education institutions. 
REAL DECRETO 1947/1995, de 1 de diciembre, por el que se establece el Plan Nacional de Evaluación de la Calidad de las Universidades

REAL DECRETO 408/2001, de 20 de abril, por el que se establece el II Plan de la Calidad de las Universidades.

REAL DECRETO 1391/2003, de 17 de noviembre, por el que deroga el Real Decreto 408/2001, de 20 de abril, por el que se establece el II Plan de la Calidad de las Universidades.

SECRETARÍA GENERAL (2000), Consejo de Universidades. Guía de evaluación de Servicios del Plan Nacional de Evaluación de la Calidad de las Universidades.

SPANISH ASSOCIATION FOR STANDARDIZATION AND CERTIFICATION (2008), AENOR. UNE standard 93.200:2008. Service charters. Requirements. AENOR, Madrid, España.

\section{Electronic sources}

EUROPEAN ASSOCIATION FOR QUALITY ASSURANCE IN HIGHER EDUCATION (2005), Criterios y Directrices para la Garantía de Calidad en el Espacio Europeo de Educación Superior. Recuperado el 21 de diciembre de 2011 de: http://www.enqa.eu

SECRETARIA GENERAL DE UNIVERSIDADES, MINISTERIO DE EDUCACIÓN (2010). Estrategia Universidad 2015. Contribución de las Universidades al progreso socioeconómico español 2010-2015. Recuperado el 21 de diciembre de 2011 de: http://www.educacion.gob.es/eu2015

PLAN DE CALIDAD DE LOS SERVICIOS UNIVERSITARIOS UNIVERSIDAD DE MURCIA 2011-2014.

http://www.um.es/unica/plan-servicios-umu/plan-calidad11.pdf

Sistema Integrado de Gestión de la Calidad de los Servicios y Unidades Administrativas de la Universidad de Jaén (2011). Universidad de Jaén:

http://telescopi.upc.edu/bdcasos/telescopi?page=bp_ver\&tipo=..\&area=0\&keyword= \&pais $=\&$ pagina $=1 \&$ id $=150$

Sistema de Gestión de la Calidad de los Servicios de la Universidad de Oviedo http://procesos.uniovi.es/mapaprocesos/

UNIVERSITY OF OVIEDO, http://calidad.uniovi.es/intranet

UNIVERSITY OF OVIEDO, http://procesos.uniovi.es/mapaprocesos/

UNIVERSITY OF OVIEDO, http://procesos.uniovi.es/mapaprocesos/ 


\section{Appendix}

\section{Universidad de Oviedo}

\section{SURVEY OF HEADS OF SERVICE}

This questionnaire is completely anonymous. Your opinion will be especially useful to improve the quality of services provided.

Score the following questions on a scale of 1 to 5 , with 1 indicating you strongly disagree or are very dissatisfied and 5 that you strongly agree or are very satisfied.

1. Has the drawing up of service charters served to publicize the information on your service?.

\begin{tabular}{|l|l|l|l|l|}
\hline 1 & 2 & 3 & 4 & 5 \\
\hline
\end{tabular}

2. Does the design of the Quality Management System provide an overview of how your service works and its utility?.

\begin{tabular}{|l|l|l|l|l|}
\hline 1 & 2 & 3 & 4 & 5 \\
\hline
\end{tabular}

3. Do you find the software application for uploading indicators useful to analyse the data on your service?.

\begin{tabular}{|l|l|l|l|l|}
\hline 1 & 2 & 3 & 4 & 5 \\
\hline
\end{tabular}

4. Does the documentary repository of available services on the Uniovi website provide you with a view of how the rest of the services provided by the University of Oviedo work?.

\begin{tabular}{|l|l|l|l|l|}
\hline 1 & 2 & 3 & 4 & 5 \\
\hline
\end{tabular}

5. Rate the work carried out by the Technical Unit for Quality for your service.

\begin{tabular}{|l|l|l|l|l|}
\hline 1 & 2 & 3 & 4 & 5 \\
\hline
\end{tabular}

6. Comments and/or suggestions for improvement 